\title{
Nursing audit: an integrating review in theses and dissertations
}

\begin{abstract}
Health services in Brazil come through several transformations, not only in the technological scenario, but in providing support services, in order to reduce costs without compromising the quality.
\end{abstract}

Objective: To investigate nursing productions with regards the audit in the database of the Centre for Studies and Research in Nursing/Nursing Brazilian Association among 2008-2014.

Method: An integrative review with a qualitative approach. The data collection was conducted from February 2015

Results: 14 scientific articles were identified and post-reading all of them, we identified five, which fit into the requirements of this research.

Conclusion: The Brazilian literature lacks studies by nurses who demonstrate the value of the audit of Nursing for health institutions related to quality of care and guidance of resources aimed to better results and patient satisfaction.

Keywords: nursing education, nursing audit, health services
Volume 4 Issue 3 - 2017

\section{Carla Vieira Amante Senna, Tatiana Martins, Tatiana Souza Kammers, Lúcia Nazareth Amante, Bruna Telemberg Sell \\ Department of Nursing, University of Southern Santa Catarina (UNISUL), Brazil}

Correspondence: Tatiana Martins, Department of Nursing, University of Southern Santa Catarina (UNISUL), Brazil, Email tatiana_martins 15@hotmail.com

Received: September 01, 2017 | Published: December 08, 2017

\section{Introduction}

Currently health services in Brazil undergo several transformations and challenges, not only in the technological scenario, but also in the provision of assistance aimed at reducing costs without compromising quality, requiring professionals to take a new dynamic in the assessment of care. It is in this context that the health audit has demonstrated that it is possible to provide patients with quality care at a fair and affordable cost. The audit is defined as a set of measures by which an internal or external auditor analyzes the operational activities, aiming to evaluate the quality of services offered and the origin of this practice since the beginning of economic activity. ${ }^{1,2}$ The term auditor originated in England in the reign of Edward I, who named him who was responsible for holding public accounts and whose testimony would lead to the punishment of those involved in infractions. In Europe, in the fifteenth and sixteenth centuries, the beginning of the audit was with the bookkeeping carried out by bookkeepers, necessary for the Italian merchant, through the accounting field. At the moment when the bookkeepers stopped reporting the accounting activity to a single merchant and began to expand to various merchants, the advisory activity began, with records dating back to 2600 BC.,4 With the Industrial Revolution in the seventeenth century, this new modality of advice received guidelines for serving large companies, arriving in the United States of America in the period of the facilities of companies responsible for railroads. In England, it was only in the eighteenth century that the audit acquired a fundamental role in the emergence of renowned companies of the time, as well as the expansion of capitalism due to the need to evaluate the accounting records of taxation of income taxes and vessels, dominated the seas and controlled world trade at the time. ${ }^{3-5}$

In Brazil, auditing had its beginning in the colonial era, but its practice was regulated after the year 1965, given the legalistic characteristics of the country. Moving forward with a trend that would consolidate in the later years, professionals and students of the accounting area published the first studies on the subject, in 1928. From 1945 that the audit discipline was inserted in the curricula of the courses of Accounting Sciences, named as Review and Accounting Skills. ${ }^{6}$

This beginning of the Brazilian audit occurred due to the facilities of subsidiaries of other countries, which followed the internal control model of its operations. The audit was effectively officialized in Brazil only in 1968 by the Central Bank of Brazil, and four years later the general auditing standards were established. In Nursing, it is practiced in public and private institutions, aiming to reduce the waste of materials; of medicines; equipment and human resources in the search for benefits not only for the health institution but also for the patients and for the nursing team itself. ${ }^{4,6-8}$

The first nursing audit publications are from the 1950s, when an American teacher developed a tool to evaluate nursing service and practice. However, the Brazilian nursing audit came in the 1970s, and in 2001 the Federal Nursing Council (COFEN) instituted Resolution 266/2001, which grants nurses professional work in auditing services. This resolution concretizes the need to have a professional auditor in the health services, since care is a complex activity that involves many actions in the promotion, prevention, treatment and rehabilitation of the assisted individual, in addition to the interaction of several sectors, aiming at multi professional assistance. It is worth mentioning that it is the nursing professionals who perform most of the procedures and accompany the patient in all periods during hospitalization., ${ }^{4,9}$

With the global transformations and the recent Brazilian financial and political scenario, health services have sought new management strategies, focusing on the need for institutions to shape a more competitive market 8 . The performance of the auditor nurse is based on his reflective critical vision, on the capacity to face the challenges within the managerial scope, on the search for new guidelines of the 
quality programs with focus on the audit work.8 In addition, the audit guides the process of continuing and permanent education, guides the activities of professionals, as well as measuring the quality of nursing care.$^{10}$ In this way, it is seen as an instrument for quality control of nursing professionals' work, being used with the intention of improving care when performed in the nursing records, after discharge from the patient. In this sense, it directs suggestions and solutions based on service analysis and gaps analysis, allowing corrective and preventive decisions to be taken to restructure the service., $4,10,11$

For this reason, the registration of nursing care in the patient's medical records in a clear and objective way, is fundamental for improvement actions, as well as evaluates if the Standard Operational Procedures (POPs) are executed correctly, guaranteeing the standardization of care and reducing the costs of medical and hospital materials. This standardization supports the facilitation of evaluation in a practical way in obtaining the results. It is observed that the audit has become an essential practice in the transformation of work processes that has been happening in hospitals and health plan operators, aiming at the restructuring to guarantee the quality of care and at the same time maintain a competitive position in the labor market. ${ }^{12,13}$ In this way, the nurse auditor, when playing his role within the ethical and legal principles of the profession, becomes fundamental in the management of health services, since it can guarantee quality of care, reduce costs, eliminate fraud, through the effectiveness of the quality of service delivery. It is understood that the graduate programs contribute to the qualification of the professionals with the accomplishment of researches that innovate and provoke the expansion of the knowledge. In this sense, the theoretical field, methods, applicability and limitations are the fruits of a critical conscience that has repercussions on health care. The Brazilian Nursing Association (ABEn), through the Center for Studies and Research in Nursing (CEPEn) maintains a bank of theses and dissertations, as it aims to encourage the development and dissemination of research carried out by nurses, in addition to preserving the professional history documentation. ${ }^{14,15}$

Considering the audit as a field of knowledge and practice of Nursing and the bank of theses and dissertations of CEPEn as a source of information on the theses and dissertations held in Brazil, the need to verify the state of the art of nursing audit theme. In this sense, an integrative review was performed in order to establish a coherent, safe and organized way about the knowledge produced from nursing audit and, thus, to contribute to the expansion of technical-scientific knowledge.

Considering the audit as an integral tool in the control of the quality in the health services, this study had as guiding question: Which scientific productions of nursing graduate programs on nursing audit are registered in the Nursing Studies and Research Center/Association Brazilian Nursing School from 2008 to 2014? As a general objective, it was aimed to evidence the scientific productions of nursing graduate programs on nursing audit registered at the Center for Studies and Research in Nursing/Brazilian Nursing Association from 2008 to 2014.

\section{Method}

Integrative review, with qualitative approach, whose data collection was performed in February 2015, developed in six stages. In the first two steps the justification, the question and the objective of the research were delineated. In the third stage the CEPEn/ABEn thesis and dissertation bank was determined as a research source.

In the fourth stage, the inclusion criteria were: thesis and dissertation summaries, focusing on nursing audit related to care; registered in the period from January 2008 to 2014, containing the words Nursing, Audit, Health Services or in the title, abstract or keywords. In the fifth stage, a critical evaluation was carried out by means of a data collection script with the following information: author, year, postgraduate program; design; participants and main results. In the sixth and final stage, the results, the discussions and the conclusion were described, considering the content analysis for theoretical appreciation. ${ }^{16}$

\section{Results}

Eleven dissertations and three theses were found in a first analysis, and six studies and three theses mentioned one of the words Nursing, Audit, Health Services, but without the deepening of the audit assisted nursing. Thus, five dissertations were selected that met the inclusion criteria, presented in Table 1.

Table I Descriptions by content analysis of the dissertations.

\begin{tabular}{llll}
\hline $\begin{array}{l}\text { Author, year, graduate } \\
\text { program }\end{array}$ & Designing
\end{tabular}

STRAUCH FL Graduation
in Nursing at the Federal
University of Santa
Catarina

Descriptive exploratory
Audit nurses who work in the audit of the SNA/SUS of a state of the South region of Brazil
Female profile of the workforce; Professionals with practical experience and theoretical qualification to carry out the audit activity;

The theme "nursing audit" does not exist in the discourse of the participants. Activities performed by the audit nurses follow what is prescribed in the SNA/SUS manuals.

They do not perform a nursing audit, but they identify the importance of performing this activity.

The need for a nursing audit is recognized by the nurses, but it is far from practical implementation in the SUS. 
Table Continued....

\begin{tabular}{|c|c|c|c|}
\hline $\begin{array}{l}\text { Author, year, graduate } \\
\text { program }\end{array}$ & Designing & Participants & Main results \\
\hline $\begin{array}{l}\text { PADILHA DF Master's } \\
\text { Program in Nursing, State } \\
\text { University of Maringá. }\end{array}$ & $\begin{array}{l}\text { Descriptive, observational } \\
\text { and documentary analysis, } \\
\text { with quantitative approach }\end{array}$ & $\begin{array}{l}50 \text { patients admitted to the UTIA/ } \\
\text { HUP }\end{array}$ & $\begin{array}{l}\text { Few nursing care was considered of } \\
\text { quality; } \\
\text { The records made by the nursing team } \\
\text { leave to be desired, since they do not } \\
\text { meet the established criteria. }\end{array}$ \\
\hline $\begin{array}{l}\text { TEIXEIRA, RVL 20I2. } \\
\text { Postgraduate Program } \\
\text { in Nursing Management, } \\
\text { University of São Paulo } \\
\text { School of Nursing. }\end{array}$ & Retrospective & $\begin{array}{l}\text { Clinical and accounting records of } \\
\text { I } 68 \text { patients. }\end{array}$ & $\begin{array}{l}\text { From the total billing of the selected } \\
\text { sample, the nursing activities contributed } \\
\text { with } 1.7 \% \text { of the billing and } 0.65 \% \text { to } \\
\text { the procedures performed through the } \\
\text { prescription of nursing and also } 1.05 \% \text { to } \\
\text { the procedures coming from the medical } \\
\text { prescription. }\end{array}$ \\
\hline
\end{tabular}

\author{
GUERRER, GFF 2012; \\ Graduate Program in \\ Nursing Management, \\ University of São Paulo \\ School of Nursing.
}

BORSATO, F.G; 2012 PostGraduation Program in Nursing, State University of Londrina. 2012.

\section{Exploratory, descriptive,} retrospective, quantitative approach

2,613 accounts pre-analyzed by the audit team.

Disability and the lack of uniformity of the records of the health team.

Need to advance knowledge about auditing hospital bills.

Registration on the process of implementation of the evaluation, contained in minutes of meetings and activity reports, and management reports carried out in the adult hospitalization unit.
Retrospective, descriptive, quantitative approach

\section{Discussion}

The dissertations selected and analyzed for this research were: one from the Graduate Program in Nursing at the Federal University of Santa Catarina, ${ }^{17}$ one from the Master's Program in Nursing at the State University of Maringá, ${ }^{18}$ two from the Graduate Program in Nursing Management at the University of São Paulo School of Nursing ${ }^{19,20}$ and one from the Postgraduate Program in Nursing at the State University of Londrina. ${ }^{21}$

It was observed that some of the studies presented the nurse as a professional capable of managing costs and administering the organizations to ensure an adequate cost/benefit ratio. In this sense, the nurse auditor acts in front of the analysis of hospital bills, financial decisions in health institutions, managing the costs associated with nursing care. The nurse must have knowledge about the procedures performed at the institution to avoid significant financial losses, observing the glosses regarding the procedures performed and not correctly checked in the medical prescription. ${ }^{12,19,20}$

The financial difficulties in public and private organizations are due to the increase of costs with the insertion of equipment capable of capturing images and information, registering, controlling and managing new diagnostic and therapeutic methods to meet the health needs of the population. Therefore, the health system is facing obstacles in the management of resources in response to the growing demands of the population, and it is necessary to seek new strategies and solutions to control costs and expenses through standardization of procedures. ${ }^{20}$

The lack of standardization of procedures may lead to an undue collection of the same activity, culminating in divergence of what is performed and what is charged, resulting in the glosses. Another relevant factor for the application of glosses is the absence of incomplete records or records. In this way, knowledge about costs must be disseminated throughout the health team in order to favor the quality of care and the billing process. Knowledge of the process of hospital cost formation by the multidisciplinary team will allow a reduction of current and future incongruities between the medical records and the hospital bill. ${ }^{19,20}$ Knowing how to recognize the costs of health services enables the identification of situations that need to be reduced, through containment, administration of expenses and elimination of waste, obtaining efficiency and quality of care. In this context, the nurse seeks tools and managerial resources that contribute to the efficiency of services in relation to the use of processes that are offered to him..$^{20}$

The nurse is a professional who has gained more and more space in the scope of financial decisions in health institutions, since their participation in the management of costs is associated to the activities performed in nursing practice, which contributes to the billing of hospital units, as is the case of the Intensive Care Unit (ICU). A study performed at a cardiology ICU of a philanthropic hospital in the city of, for a period of three months with a sample of 168 patients, identified an average billing generated by the nursing prescriptions of 333.06 reais and by the medical 440.92 reais, totaling 773.98 reais. Bringing the focus to nursing, the procedures of the nursing prescriptions that contributed the most to the billing were: exchange of bacterial filter $(10,342,80$ reais), venipuncture technique $(8.062,99$ reais), procedure of exchange of curatives of the sites (5,315.26 reais) and tracheostomy dressings (4,762.42 reais). Regarding total billing, the activities performed by the nursing team reached $1.7 \%$ of the billing and $0.65 \%$ were related to the procedures performed through nursing prescription. ${ }^{19}$

There were some gaps related to nursing billing, such as the accentuated volume of procedures performed linked to the patients' 
account, in which the monetary value was not accounted for individually, thus, the financial return was not identified. In addition, it was seen that in the analysis of patients' accounts, some procedures were not collected, such as a nasal catheterization and inhalation facility. ${ }^{19}$

Nursing services are considered to be the most costly, and there is no knowledge of the return on expenses, which has repercussions for obtaining and maintaining the ideal resources necessary for safe care. As a solution, accounting auditing services have been created, carried out by nurses who work on the analysis of medical records as controllers; brokers; negotiators and agents in the process of gloss resources, aiming to increase hospital billing. ${ }^{19}$

In a study conducted at the University of São Paulo, 2,613 accounts were analyzed by the hospital's own audit team for the period from January to December 2011. The turnover was concentrated in four of the 34 health plan operators accredited. There was a predominance of one operator $(27.6 \%)$, but the highest average value per account was from another operator. Regarding the materials, the most items included in the accounts by the nurses were gases $(90.5 \%)$, materials for hospitalization (85\%) and nursing services (83.2\%). Regarding the analyzed accounts, $91.42 \%$ received adjustments. Regarding the excess of adjustments, the deficiency and the lack of standardization of the records of the entire multidisciplinary team were evident. These losses in the billing are related to the financial loss due to the lack of collection of the items used during the hospitalization of the patient. It was observed that in the pre-analysis of the hospital accounts, the lack of records that supported the collection from the procedure was constantly identified. ${ }^{20}$

In this sense, the study of records, both notes related to health care and incorrect completion of debit notes, was identified as necessary since they were completed, since incomplete records cause imbalance in hospital billing. The incomplete, incorrect or even absent registration of the nursing and medical team, besides compromising the institution's billing, favor the occurrence of errors that generate damages and adverse events to the patient. In addition, spelling errors; unreadable letters; use of inappropriate terms and acronyms; lack of identification of the professional who made the notes; were often detected. Consequently, there is an association between the records and the quality of nursing care, both of which did not meet the criteria established in the evaluation of physical activity; ventilation; oxygenation; hygiene; comfort and organizational aspects. However, the scope of quality criteria for physical safety and the use of equipment ${ }^{11,18,20}$ was evinced.

From the ethical and legal point of view, inadequate nursing records imply responsibility for the professional, which can account for the damages caused to the patients and the financial losses of the institutions. It should be emphasized that it is a legal obligation of the nursing professional to correctly record their activities, and the institution should establish norms and routines that guide both the correct record and the correction of an inadequate record. It was verified the need to implement educational measures to obtain quality in the registries and care provided, with the awareness of the professionals to the reliable registry which favors the continuity of patient care and safety. ${ }^{8-22}$

The performance of the nurse auditor has repercussions on the quality of care provided to the patient and on the technical control of the procedures, as well as their participation in accreditation activities and surveys of medical specialties, and can collaborate in the investigation of complaints related to problems in the health system. Therefore, the performance of this professional meets the purpose of the nursing audit, guaranteed by the Nursing Professional Exercise Law No. 7498/1986, which is to contribute to improving the quality of care provided to users; to evaluate the provision of health services, which should be correlated with the principles and guidelines of the Unified Health System (SUS) with a view to improving and maintaining the quality of care offered. It is a tool that contributes to the improvement of health services and practices, mainly in diverse and complex structures such as the SUS system. At the same time, it should be emphasized that the quality of the nursing record contributes positively to multidisciplinary communication, but often the shortage of nursing staff in hospitals makes it difficult to record information. ${ }^{13,17,23}$

The evaluation of the quality of the nursing service has repercussions on the improvement of care due to an improvement in hygiene care, assistance in moving and walking, silence in the unit, lighting, physical security, discharge justifications and evaluations pertinent to each of the procedures performed, regarding the strict clinical control and adequate management of the organizational financial costs. Since nursing provides care for 24 hours, it ends up assuming the responsibility of reporting minutely the occurrences and daily interventions, such as: nursing prescription, administration of medications prescribed by other professionals, description of procedures and intercurrences, record of the use of equipment and materials consumption during work practice. ${ }^{24}$

Internal audit performed by nurses can be useful in assessing the quality of care, as it verifies patient satisfaction as well as adequacy or even the need for financial resources. ${ }^{4,6}$ Although the work of nurses is essential in the billing of financial institutions, due to the knowledge of procedures, routines, materials and equipment, it is observed that there is a gap in the labor market of nurses working in the commercial area of hospitals. In some hospitals, the preparation of accounts and the analysis of medical records are carried out by administrative assistants who do not have technical-scientific knowledge to analyze nursing procedures. Given this, nursing auditing is an area to be implemented, since it contributes to improving the quality of care and to the correct application of financial resources, improving patient outcomes and satisfaction. ${ }^{18,19}$ Another adversary encountered by the auditors is the routine observation of failures in nursing reports, which are due to the lack of appropriate methodology and standardization for the development of these records. To that end, the auditor nurse is committed to perform the practice contributing to the quality of health care, and its role is relevant because it has skills in the areas of care, administration, teaching and research. ${ }^{17,24}$

Considering the scope of the auditor's performance in nursing, there are some negative points such as: lack of clarity of the activity; lack of professional members the multidisciplinary team; lack of information in nursing records; non-recognition of the staff of other specialties regarding the need for the nursing audit and the absence of feedback from their hospital managers and administrators, once the audit issues an opinion and provides solutions. It reinforces that audit results contribute to the improvement of health services and practices, including aid to diversified and complex institutions. ${ }^{17}$

\section{Conclusion}

After the analysis of the scientific productions of nursing audit it is possible to emphasize that the nurse contributes to the improvement in the quality of the assistance and participates in the identification of 
factors that lead to the reduction of costs. It was verified that one of the major challenges in this area, to be faced by the registered nurses, is the nursing record that has been incompletely, incorrectly or even not annotated in the patient's medical record, making it difficult to analyze and billing of hospital bills, as well as compromising patient safety. Therefore, continuous and ongoing education activities are recommended to promote the awareness of the nursing team to complete the notes in a complete and concise manner. Much progress has been made in the nursing audit process, but there is much to be done in order for this practice to contribute definitively and efficiently to the objectives and actions proposed, and the audit should be understood as an educational method in which responsibility for failure is not sought, but rather the questioning of the adverse outcome.

It is proposed to include the subject of auditing in the technical training and undergraduate courses in nursing, considering its transversality, promoting the incorporation of this new area in the profile of professionals. On the other hand, it is necessary to promote lines of research for the provision of studies that show the advances and difficulties in the quality of the nursing service, especially with regard to registries.

\section{Acknowledgements}

None.

\section{Conflict of interest}

The author declares no conflict of interest.

\section{References}

1. Souza DA, Fonseca AS. Auditoria em enfermagem: visão das enfermeiras do município de São Paulo. Revista Nursing. 2005;8(84):8.

2. Passos MLL. Auditoria de enfermagem: conhecimento de profissionais em hospital público de referência. Rev Rene. 2012;13(5):1025-1033.

3. Kurcgant P. Administração em enfermagem. Brazil: São Paulo; 2006.

4. Pinto KA, Melo CMM. A prática da enfermeira em auditoria em saúde. Revista da Escola de Enfermagem da USP. 2010;44(3):671-78.

5. Riolino A, Kliukas G. Relato de experiência de enfermeiras no campo de auditoria em prontuário: uma ação inovadora. Revista Nursing. 2003;65(65):35-39.

6. Ricardino A, Carvalho NL. Breve retrospectiva do desenvolvimento das atividades de auditoria no Brasil. Revista Contabilidade \& Finanças. 2004; 15(35):22-34.

7. Niyama JK. Contabilidade internacional São Paul. Brazil; 2006.

8. Silva MVS, Silva LMS, Dourado HHM, et al. Limites e possibilidades da auditoria em enfermagem e seus aspectos teóricos e práticos. Revista brasileira de enfermagem. 2012;65(3):535-538.
9. Conselho Federal de Enfermagem. Resolução n. 266, de 05 de outubro de 2001. Aprova atividades de Enfermeiro Auditor, Resolução COFEN; 2001.

10. Faraco MM, Albuquerque GL. Auditoria do método de assistência de enfermagem. Revista brasileira de enfermagem. 2004;57(4):421-424.

11. Setz VG, D’innocenzo M. Avaliação da qualidade dos registros de enfermagem no prontuário por meio da auditoria. Acta Paul Enferm. 2009;22(3):313-317.

12. Scarparo AF, Ferraz CA. Auditoria em Enfermagem: identificando sua concepção e métodos. Revista brasileira de enfermagem. 2008;61(3):302-305.

13. Dias TCL, Santos JLG, Cordenuzzi OCP, et al. Auditoria em enfermagem: revisão sistemática de literatura. Revista brasileira de enfermagem. 2011;64(5):931-937.

14. Abrahão CMM. A importância da auditoria em enfermagem frente à qualidade assistencial no âmbito hospitalar público [Monografia]. Brasília: Centro Universitário de Brasília, Brazil: Springer; 2013.

15. Leite JL. Oliveira DC Centro de estudos e pesquisa em enfermagem e a ABEN: 80 anos de desafios. $R$ Enferm UERJ. 2006;14(2):161-162.

16. Bardin L. Análise de Conteúdo. Lisboa, Edições 70, Portugal: Springer; 2011.

17. Strauch FL. Enfermeira auditora do Sistema Único de Saúde: perfil, atividades e percepções [Dissertação]. Florianópolis: Universidade Federal de Santa Catarina, Brazil: Springer; 2009.

18. Padilha EF. Auditoria como ferramenta para a qualidade do cuidado de enfermagem em unidade de terapia intensiva de um hospital universitário. Maringá: Programa de Mestrado em Enfermagem da Universidade Estadual de Maringá, Brazil: Springer; 2010.

19. Teixeira RVL. O retorno financeiro das atividades realizadas pela enfermagem em uma unidade de terapia intensiva [Dissertação]. São Paulo: Programa de Pós-Graduação em Gerenciamento de Enfermagem da Escola de Enfermagem Universidade de São Paulo; 2012.

20. Guerrer GFF. Auditoria de contas em um hospital de ensino especializado em cardiologia e pneumologia: um estudo de caso [Dissertação]. Brazil: São Paulo; 2012.

21. Borsato FG. Avaliação da qualidade da assistência de enfermagem em um hospital público de média complexidade; 2012.

22. Valença $\mathrm{CN}$, Azevêdo LMN, Oliveira AG, et al. A produção científica sobre auditoria de enfermagem e qualidade dos registros. $R$ pes cuid fundam. 2013;5(5):69-76.

23. Brasil. Lei $n^{\circ} 7.498$, de 25 de junho de 1986. Dispõe sobre a regulamentação do exercício da enfermagem, e dá outras providências. Portal da Legislação: Leis Ordinárias. Brasil; 2015.

24. Souza JSM, Beltrame V, Stumpf CC, et al. Dificuldades na auditoria de enfermagem no estado de Santa Catarina. Evidência. 2011;11(2):45-56. 